\title{
Macroeconomic Adjustment and Institutional Reforms in the Euro Area
}

\author{
Christian Keuschnigg $^{1}$ - Klaus Weyerstrass ${ }^{2,3}$
}

Published online: 7 June 2015

(C) International Atlantic Economic Society 2015

\begin{abstract}
The introduction of the Euro in 1999 implied the transfer of the responsibility for monetary policy to the European Central Bank and it eliminated the member countries' nominal exchange rates. The smooth operation of a common currency area requires that independent exchange rates are replaced by other adjustment mechanisms. In the Euro area, wages have not been flexible enough, labor mobility is low, no sufficient central fiscal institutions exist, and the fiscal rules have been weak. This led to large external imbalances and high public debt in some countries. Since the outbreak of the economic crisis, macroeconomic reforms resulted in improved international competitiveness and lower public deficits. Several new institutions have been created on the European level, strengthening mutual economic surveillance and cooperation.
\end{abstract}

Keywords Euro area · Macroeconomic adjustment · International competitiveness · Fiscal federalism $\cdot$ Banking union

JEL Classification $\mathrm{E} 62 \cdot \mathrm{G} 20 \cdot \mathrm{H} 62$

\section{Introduction}

With the introduction of the Euro, the exchange rate risk among the member states was eliminated. Financial market participants evidently misperceived the sovereign risks,

The authors are grateful to comments by participants of the 2012 INFER Annual Conference in Pescara, Italy, where an earlier version of this paper was presented.

Klaus Weyerstrass

klaus.weyerstrass@ihs.ac.at

1 University of St. Gallen, CEPR and CESifo, St. Gallen, Switzerland

2 Department of Economics and Finance, Institute for Advanced Studies (IHS), Stumpergasse 56, 1060 Vienna, Austria

3 Economica Institute of Economic Research, Vienna, Austria 
since the interest rate differential relative to Germany decreased substantially and remained very low for many years. When the sovereign debt crisis began to take hold, the markets made reassessments, and interest rates on the vulnerable sovereigns began to rise rapidly (Honkapohja 2013). The real catching-up process in the peripheral countries supported high wage and price increases. Since these wage increases exceeded productivity growth, international price competitiveness was eroded, making the single currency too strong for these countries. In the wake of the financial and economic crisis, growth stopped, making private and public debt levels unsustainable. Since the outbreak of the crisis, reforms and economic adjustment in the crisis-struck countries began to result in higher international price competitiveness and lower fiscal deficits. The fiscal and macroeconomic reforms negatively affect domestic demand in the short run or even in the medium run, but they create the basis for higher and more sustainable growth in the future. At the same time, the Euro area has reacted to the financial and economic crisis by creating several new institutions, strengthening the mutual economic surveillance and cooperation of the member states.

In this paper, we discuss reasons for the severe financial and sovereign debt crisis in the Euro area. Then, financial assistance provided for those countries which were confronted with very high interest rates on government bonds are discussed. Furthermore, the reforms of economic policy governance in the European Union are addressed, with an emphasis on the banking union and on the issue of more fiscal integration in the European Union (EU). A substantial part of the paper is devoted to fiscal and macroeconomic reforms undertaken on the level of the member states.

\section{Emergence of the Crisis}

The introduction of the common currency in 1999 implied the transfer of the responsibility for monetary policy to the European Central Bank (ECB). It also eliminated independent nominal exchange rates as key instruments that could adjust to avoid large trade imbalances and unsustainable international borrowing. The smooth operation of a common currency area requires that independent exchange rates are replaced by other adjustment mechanisms. The theory of optimal currency areas (OCA) mentions four such mechanisms (e.g., Beetsma and Giuliodori 2010; Buiter and Rahbari 2011; De Grauwe 2009; Feldstein 2011; Keuschnigg 2012; Lane 2006; Lane 2012; Sapir 2011; Shambaugh 2012; Sinn and Wollmershäuser 2011) (i) wage flexibility to align unit labor costs with international competitiveness, (ii) labor mobility, (iii) central fiscal institutions to provide insurance against asymmetric shocks, and (iv) strict fiscal rules to prevent negative spillovers of national fiscal policies on other member countries. In the Euro area, none of these four conditions for an OCA are fulfilled. Only in a few member countries are wages sufficiently flexible. Due to cultural and language barriers, labor mobility across countries is low in Europe. The European Union budget is far too small to achieve any significant automatic stabilization in the case of a negative economic shock. Finally, the fiscal rules of the Maastricht treaty have not been credible and have been plainly ineffective in preventing the current sovereign debt crisis in the Euro area. When the large member states, Germany and France, violated these principles in the first place, this sent out a clear signal to the smaller member states that they would not have to fear any consequences should they breach the thresholds. 
If a country loses competitiveness, external devaluation would make exports cheaper on world markets and render imports more expensive. In the Euro area, external devaluation is not possible for the individual member countries and must be replaced with internal devaluation that reduces unit labor costs to regain competitiveness in the tradable sector. A country may also improve competitiveness by 'fiscal depreciation' which shifts the tax burden away from labor towards indirect taxes in order to reduce labor costs. Internal devaluation often leads to income losses and transitional unemployment, but it is necessary to reduce external deficits. A reallocation of production factors from the non-tradable to the tradable sector is required. For structural change to be successful, labor market reforms must allow the termination of unprofitable employment as a precondition for new jobs in more competitive and profitable sectors. Transitional income losses diminish demand and production in the non-tradable sector faster than new jobs can be created in the international sector. If internal devaluation is undertaken abruptly, the country experiences a severe adjustment recession. It might be argued that in some countries, which have accumulated such high public debt levels and external deficits that very severe fiscal austerity measures and substantial wage decreases would be required, should leave the Euro area (Allen and Ngai 2012). In this case, a large one-off depreciation would immediately restore competitiveness and speed up new export led growth. However, a sharp external devaluation upon a Euro area exit would cause substantial social costs in terms of higher import prices. Furthermore, once one country leaves the Euro area, financial markets might speculate on the exit of other countries. Hence, the credibility of the Euro would be threatened.

The current account crisis in southern periphery countries is partly a result of capital market failure. Prior to the introduction of the Euro, countries with competitiveness problems faced substantially higher interest rates to compensate for the exchange rate risk. These risk premia disappeared with the introduction of the Euro as sovereign default seemed highly implausible, despite the no bail-out clause in the Maastricht treaty. Easy access to credit at record low interest rates fuelled a large investment and real estate boom. Many of these investments would not have been profitable had market interest rates included an adequate risk premium.

Rapid demand growth prior to 2008, financed with large capital inflows, encouraged wage and price increases not backed by real productivity growth, hence eroding international competitiveness. These developments led to large private and public sector debt, current account deficits and foreign indebtedness. Correcting these imbalances requires foremost the realigning of wages with labor productivity and achieving higher labor and product market flexibility. As early as 2006, the European Commission stated that the economic development in the first years of monetary union had been marked by significant and persistent divergences between the member states regarding real GDP growth, inflation, intra Euro-area real effective exchange rates, current account balances and residential housing investment (European Commission 2006).

\section{Financial Assistance Programs}

After the outbreak of the crisis in 2008, substantial financial assistance had to be provided to some member states. When government bond yields increased significantly 
during the crisis, some countries were no longer able to finance their public budgets on the capital market. Financial assistance was first provided bilaterally by the individual member states. Later on, further assistance was financed by the European Financial Stability Facility (EFSF). The loans were provided under strict conditions regarding macroeconomic and fiscal reforms. The implementation of these reforms is continuously monitored by a so-called Troika with experts from the European Commission, the ECB and the Internal Monetary Fund (IMF). The bilateral loans proved to be not sufficient to bring government bond yields down for Greece. In addition, other Euro area countries came under pressure from financial markets. Hence, the European Council and the ECB decided to establish a temporary rescue package, involving mainly guarantees. This package consisted of the European Financial Stabilisation Mechanism (EFSM), the European Financial Stability Facility (EFSF) and IMF loans. As these temporary measures were still insufficient to restore confidence of financial market participants into the sustainability of the Euro area, policy makers decided to establish the European Stability Mechanism (ESM), a permanent resolution mechanism, Financial assistance from the ESM is only activated upon a request from a member state and is subject to strict condition regarding economic and fiscal reforms. ${ }^{1}$

\section{Reform of EU Governance}

As a reaction to the financial and economic crisis, the EU initiated several reforms of the economic policy framework. Strengthening policy coordination and multilateral surveillance is an attempt to prevent the build-up of large macroeconomic imbalances and keep public debt under control so as to avoid future bail-outs of member countries. Initially, such financial assistance and bail-outs were excluded by the Maastricht treaty and the Stability and Growth Pact (SGP), but these rules were not credible. Future fiscal policy rules will have to be more credible. Institutional reforms include the European Semester, the Six-pack and the Treaty on Stability, Coordination and Governance (TSCG), of which the fiscal part is known as the Fiscal Compact. The Six-pack not only covers fiscal surveillance, but also macroeconomic surveillance under the new Macroeconomic Imbalance Procedure (MIP).

\section{Reforms of the Fiscal Policy Framework}

In the fiscal field, the Six-pack strengthens the SGP. According to the SGP, the EU member states' budget balance shall converge towards the country-specific mediumterm objective (MTO), the general government deficit must not exceed $3 \%$ of GDP and public debt must not exceed $60 \%$ of GDP. The Six-pack envisages a stricter application of the fiscal rules by defining quantitatively what a significant deviation from the MTO or the adjustment path towards it means. Moreover, the Six-pack strengthens the debt criterion.

The Fiscal Compact requires governments to ensure convergence of the fiscal balance towards the country-specific medium-term objective, with an upper limit of a structural deficit (cyclical effects and one-off measures are not taken into account) of

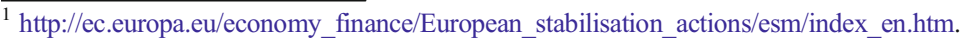


$0.5 \%$ of GDP (1.0\% of GDP for member states with a debt ratio significantly below $60 \%$ ). Furthermore, member states with government debt exceeding $60 \%$ in relation to GDP shall reduce it at an average rate of at least $1 / 20$ per year of the exceeded percentage points. Correction mechanisms should ensure automatic action to be undertaken in case of a deviation from the MTO or the adjustment path towards it. These rules have to be implemented in national law through provisions of binding force and permanent character, preferably constitutional.

\section{Detecting and Correcting Macroeconomic Imbalances}

Recognizing the fact that the budgetary problems which some member states are confronted with are to a large extent rooted in the erosion of international competitiveness and the resulting build-up of macroeconomic imbalances, the EU has also introduced a procedure that aims at preventing and, if necessary, timely correcting macroeconomic imbalances. This Macroeconomic Imbalance Procedure (MIP) is a surveillance mechanism that aims to identify potential risks at an early stage. An alert system has been established based on a scoreboard consisting of a set of eleven indicators covering the major external and internal sources of macroeconomic imbalances, like the development of real exchange rates, public deficits and real estate prices. The MIP has also a corrective arm which applies if significant macroeconomic imbalances in individual member states have been identified. ${ }^{2}$

\section{Banking Union}

The financial crisis showed clearly that the lack of a common financial supervisory and bank resolution mechanism was a major omission in the EU Single Market Program. The lacking of a banking union contributed to the build-up of financial imbalances. The financial crisis mutually reinforced the accumulation of public debt and losses in the banking sector. The financial architecture in Europe suffers from two problems (see Brunnermeier et al. 2011, and Beck et al. 2011). First, the absence of a Europe-wide safe asset induces capital flight from risky to safe countries in times of crisis. Second, government bonds have zero risk weight in calculating minimum equity ratios so that banks do not need to raise equity when they hold more risky government bonds. The ECB suffers from this regulatory failure and from the problem that it has to accept ever weaker assets as collateral to allow refinancing of banks in crisis countries. By accepting low quality assets as collateral, it allows banks to hold bonds of their own governments and thereby reinforces the vicious loop between sovereign and banking risks. To strengthen the resilience of banks, a higher share of credit and other assets must be propped up with shock absorbing equity. The equity share must be larger for banks that follow riskier investment strategies. Higher shares of equity or similar financial instruments not only reduce the systemic risk within a country but also reduce the risk of contagion for other countries in the Euro area.

In July 2013, the European Commission proposed to create a single resolution mechanism (SRM). After the agreement on a single supervisory mechanism (SSM),

\footnotetext{
$\overline{2}$ http://ec.europa.eu/economy_finance/economic_governance/macroeconomic_imbalance_procedure/index_ en.htm
} 
this was the next step towards a banking union, necessary to prevent bank bail-outs. The financial crisis, including the need to bail out the banking sector in Cyprus, highlighted the need for an EU-wide funding arrangement financed by the banking sector. A single European supervisory mechanism for banks has to go hand in hand with a single bank resolution scheme. Otherwise, tensions between the supervisor (ECB) and national resolution authorities could emerge over how to deal with ailing banks. A single resolution fund (SRF) is established over a period of eight years. It is fed by bank levies at a national level, finally reaching 55 billion Euro or $1 \%$ of all guaranteed deposits.

\section{Fiscal Union}

In addition to the establishment of a banking union, the crisis has given rise to a debate concerning deeper fiscal integration in Europe. Based on simulations with a multicountry macroeconomic model, Bargain et al. (2013) conclude that further fiscal integration could improve fiscal stabilizers in the Euro area and reduce the vulnerability of individual member states to income shocks. But limited improvement in fiscal stabilizers goes along with considerable income redistribution between countries. Therefore, it remains necessary to improve macroeconomic stability by increasing wage and price flexibility on the level of the member states rather than by resorting to more cross-country income redistribution in the EU.

\section{Adjustment Progress in the Member States}

This section evaluates the macroeconomic adjustment progress which the crisis-struck countries have made so far. ${ }^{3}$ Cyprus is not considered due to the short time period that elapsed since the outbreak of the crisis. For the assessment of the adjustment progress, the following indicators are taken into account:

- Public finances. The key indicator for the sustainability of public finances is the debt level in relation to gross domestic product (GDP). The observation that in most cases the debt ratio is still increasing is largely due to the fact that the adjustments in the real economy, but also the negative impact of fiscal adjustments on private and public demand, contribute to low or even negative economic growth, resulting in high unemployment. Hence, fiscal adjustment is assessed with respect to the overall budget balance, the structural budget balance and the primary budget balance, all in relation to nominal GDP.

- International competitiveness. The main measure of international price competitiveness is the real effective exchange rate (REER), which is here calculated on the basis of GDP deflators. Furthermore, the competitiveness indicator of the World Economic Forum (WEF) as a comprehensive measure for the institutional arrangement in the countries is included.

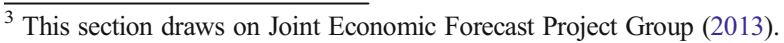


- Current account. Large current account deficits have resulted in high external debt in the crisis-struck countries. The adjustment progress is sensibly not measured with respect to debt levels, but with a view to current account balances.

Figure 1 summarizes the adjustment progress. For each country, the realizations of the above mentioned indicators at the peak in the crisis (denoted 'Crisis') are compared with their realizations at the end of 2013 (denoted 'The adjustment'). The dates of the crisis peak vary between indicators (current account balance and real effective exchange rate: 2008; public budget balance, primary budget balance, structural budget balance: 2009; WEF indicator: 2010), but they are identical for each indicator over the countries. Each outer value in the figure is identified by the largest value of each indicator, and this extreme value is then normalized to 1 . The center of each country panel is defined by this scaling, and hence it does not represent any explicit target value. As an example, the most negative value of the current account balance was reached in Greece in 2008 with $-15 \%$ of GDP. Hence, the 'Crisis' realization of the current account balance is located on the outer border in the panel for Greece. The distance between the lines 'Crisis' and 'Adjustment' indicates the adjustment progress made for each indicator in each country.

All considered countries have made progress in the adjustment towards sustainable public finances and a competitive economy. However, the speed of adjustment as well as the achieved progress differs considerably between countries. Ireland was the first country to initiate structural reforms. Other countries began their reforms later and are lacking substantially behind Ireland regarding the reduction of their internal and external imbalances. At least the real effective exchange rate has in the meantime depreciated in all considered countries, and this improvement in the international price competitiveness has resulted in a sizeable decline in the current account imbalances. This was not only due to recession-induced shrinking imports, but also rising exports. Positive developments regarding international competitiveness and consolidating public finances are also stated by the European Commission, the ECB and the IMF in their progress reports on the so-called Program Countries, i.e. those countries that received financial assistance (Ireland, Portugal, Spain, Greece and Cyprus). Differences in the adjustment progress are not least determined by divergences regarding regulations and institutions. Among the considered countries, Ireland is ranked highest regarding competitiveness in the WEF indicator. This is also reflected in the World Bank's ease of doing business indicator. At the other side of the spectrum, Greece and Italy are ranked at the bottom among all OECD countries, clearly indicating the deficiencies of these countries regarding structural change.

\section{Bank Capitalization}

The financial crisis revealed clearly that many banks in the Euro area were too weakly endowed with equity. Due to the recession, more and more loans to the private nonfinancial sector became non-performing. As Table 1 shows, in Ireland the share of nonperforming loans soared from just $1 \%$ prior to the crisis to almost $17 \%$ at the end of 2013. Also in the other crisis countries, the share of non-performing loans rose substantially, particularly in Cyprus and Greece. 

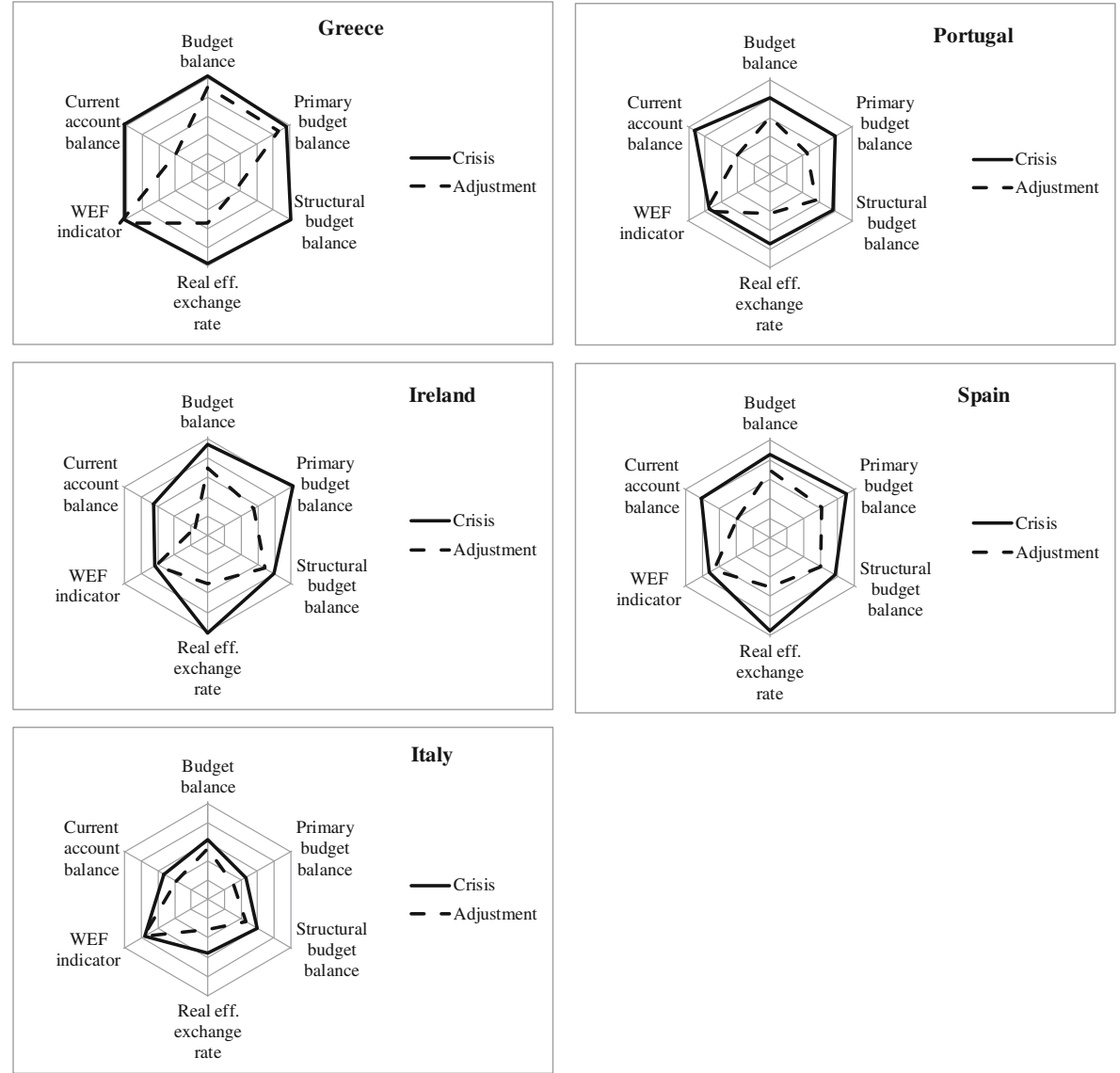

Fig. 1 Adjustment progress in the crisis countries. Sources: Eurostat; ECB; World Economic Forum; Joint Economic Forecast Project Group; authors' calculations

Due to the systemic relevance of banks and the importance of a stable credit supply to the private sector, governments had to re-capitalize banks, further raising budget deficits and public debt. As a consequence, the new European regulatory framework requires that banks have to hold more equity. These new regulations have already resulted in considerable improvements in the capital endowment of European banks, as Fig. 2 shows. Particularly Irish banks managed to improve their equity substantially.

The adjustment in international price competitiveness as well as regarding the banking sector reforms has strengthened the confidence of international investors into the financial and macroeconomic stability of the peripheral Euro area countries. This is visible in a reversal of capital flows, i.e. a stop of capital flight from the peripheral countries. The normalization of financial markets was also a result of interventions by the ECB. On August 2, 2012, the ECB announced its OMT (Outright Monetary Transactions) program. Under OMT, the Eurosystem may buy government bonds that mature in one to three years under the condition that the bond-issuing countries agree to domestic adjustment measures. The announcement of the OMT program stabilized 
Table 1 Bank non-performing loans as a percent of total loans

\begin{tabular}{lrrrrrrr}
\hline & 2000 & 2008 & 2009 & 2010 & 2011 & 2012 & 2013 \\
\hline Ireland & 1.0 & 2.6 & 9.0 & 8.6 & 12.8 & 16.6 & 18.4 \\
Greece & 12.3 & 3.1 & 5.2 & 7.1 & 12.1 & 17.8 & 24.2 \\
Spain & 1.2 & 2.6 & 3.6 & 4.1 & 5.2 & 6.4 & 7.9 \\
Portugal & 2.2 & 1.6 & 2.5 & 3.7 & 5.3 & 7.0 & 7.8 \\
Cyprus & n.a. & 4.2 & 4.3 & 5.4 & 12.4 & 18.7 & 33.2 \\
\hline
\end{tabular}

Source: World Bank, World Development Indicators (year 2000); ECB (from 2008 onwards)

investor confidence and eliminated speculative risk premia. However, the ECB decision announced on January 22, 2015 to buy government and corporate bonds in the amount of 60 billion Euro per month until September 2016 bears the risk of fuelling housing and share price bubbles, and it creates moral hazard problems. Such an intervention generates negative incentives, as it reduces the pressure on governments to implement unpopular, but necessary structural reforms. Risk premia are necessary signals from financial markets if they are not excessive. Large amounts of liquidity provided by the Eurosystem do not benefit loans to the real economy, but allow governments to borrow again at artificially low interest rates. Hence, the ECB intervention might stabilize financial markets in the short run, but the time bought by this policy has to be used by the governments to continue with structural reforms, securing sound public finances and generating economic growth.

\section{Conclusions}

The crisis countries have made considerable progress in restoring sound public finances and international competitiveness. However, the adjustment process is tough and slow, and some countries have been confronted with a severe adjustment recession and very high unemployment. The extent to which restrictive fiscal policies have contributed to the recession has recently been hotly debated. Blanchard and Leigh (2013) argue that this fiscal tightening is having a strong negative impact on growth. On the other hand,

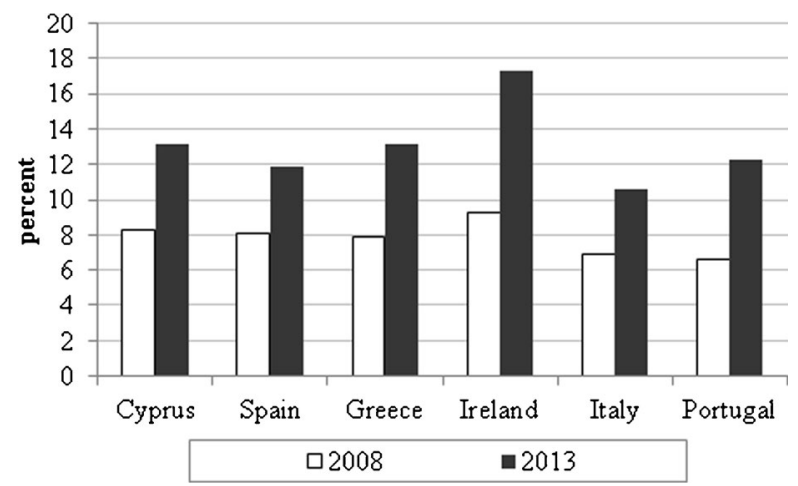

Fig. 2 Tier 1 capital ratios of banks in selected European countries. Source: ECB, author's own illustration 
the European Commission notes that fiscal vulnerabilities which in the crisis led to sharp increases in borrowing costs and tightening of credit conditions were the main reasons for the unexpectedly large negative effects on GDP of the current fiscal adjustments. Since interest rates for loans to the private sector are correlated with government bond yields, rising government bond rates in the crisis translate into higher private sector borrowing costs (European Commission 2012).

High unemployment not only implies the risk that cyclical unemployment turns into structural unemployment with negative impacts on growth potential, but it also endangers political support for the painful but necessary adjustment measures. The continuation and future success of the adjustment progress hinges on a significant improvement of the labor market. Economic growth is the key to solving the debt problem, since higher GDP growth and increasing employment generate public revenue.

Reforms undertaken since the outbreak of the crisis involve more than macroeconomic and fiscal rebalancing at the level of the member states. Of equal importance, the EU created several new institutions and strengthened mutual economic surveillance in the member states. While at the beginning of the crisis policy-makers were reacting rather than acting, over time policy-making has become more proactive so that the Euro area should now be better suited to withstand future negative shocks. Some of the new institutions involve the transfer of national responsibilities to the European level. Any decision about centralization or decentralization in Europe has to observe the principle of subsidiarity, which is laid down in the European treaties. Decisions should be as decentralized as possible, since the needs and preferences of the citizens are best known at the most decentralized level. On the other hand, some areas with substantial spillovers across countries require regulation at the central level so as to internalize any externalities. One important example of such an area is the banking union since many banks operate in many different member states.

\section{References}

Allen, F., \& Ngai, V. (2012). In what form will the eurozone emerge from the crisis? Journal of Applied Finance, 22(2), 6-19.

Bargain, O., Dolls, M., Fuest, C., Neumann, D., Peichl, A., Pestel, N., \& Siegloch, S. (2013). Fiscal union in Europe? Redistributive and stabilizing effects of a European tax-benefit system and fiscal equalization mechanism. Economic Policy, July, 375-422.

Beck, Th., Wagner, W., \& Uhlig, H. (2011). Insulating the financial sector from the european debt crisis: eurobonds without public guarantees, www.VOXeu.com/.

Beetsma, R., \& Giuliodori, M. (2010). The macroeconomic costs and benefits of the EMU and other monetary unions: an overview of recent research. Journal of Economic Literature, 48, 603-641.

Blanchard, O., \& Leigh, D. (2013). Growth forecast errors and fiscal multipliers. IMF working paper 13/1, http://www.imf.org/external/pubs/ft/wp/2013/wp1301.pdf.

Brunnermeier, M., Garicano, L., Lane, P. R., Pagano, M., Reis, R., Santos, T., Thesmar, D., van Nieuwerburgh, S. \& Vayanos, D. (2011). European Safe Bonds (ESBies), www.Euro-nomics.com/.

Buiter, W., \& Rahbari, E. (2011). The future of the euro area: fiscal union, break-up or blundering towards a 'you break it you own it Europe', Citigroup, Global Economics View, 9. September 2011.

De Grauwe, P. (2009). Economics of a monetary union. Oxford: Oxford University Press.

European Commission (2006). The EU economy: 2006 review. European Economy No 6/2006. Brussels.

European Commission (2012). European economic forecast, autumn 2012, (Box 1.5). http://ec.Europa.eu/ economy_finance/eu/forecasts/2012_autumn/box_af12_-_multipliers_en.pdf. Brussels.

Feldstein, M. (2011). The Euro and European economic conditions, NBER Working Paper WP 17617. 
Honkapohja, S. (2013), The Euro crisis: a view from the North. Bank of Finland Research Discussion Papers 12/2013.

Joint Economic Forecast Project Group (2013), German Economy Recovering-Long-Term Approach Needed to Economic Policy. Spring 2013. Halle (Saale).

Keuschnigg, Ch. (2012), Should Europe become a fiscal union?, CESifo Forum 1/2012, 35-43. Munich.

Lane, P. R. (2006). The real effects of European monetary union. Journal of Economic Perspectives, 20, 4766.

Lane, P. R. (2012). The European sovereign debt crisis. Journal of Economic Perspectives, 26, 49-68.

Sapir, A. (2011). European integration at the crossroads: a review essay on the 50th anniversary of Bela Belassa's theory of economic integration. Journal of Economic Literature, 49, 1200-1229.

Shambaugh, J. C. (2012). The Euro's three crisis, brookings papers on economic activity, vol. 44, issue 1 (Spring), 157-231.

Sinn, H.-W., \& Wollmershäuser, T. (2011). Target loans, current account balances and capital flows: The ECB's Rescue Facility, CESifo Working Paper WP 3500. Munich. 